\title{
Invasive Apocrine Breast Carcinoma
}

National Cancer Institute

\section{Source}

National Cancer Institute. Invasive Apocrine Breast Carcinoma. NCI Thesaurus. Code C5457.

An invasive breast adenocarcinoma with cytological and immunophenotypic

characteristics of apocrine differentiation in more than 90 percent of the malignant cells. 